\title{
Innovation as a New Mode of Knowledge Transfer within MNC Subsidiary
}

Jamsari Alias, Norazila Mat, Nazri Muslim, Nur Atiqah Abdullah, \& Rosmila Senik

To Link this Article: http://dx.doi.org/10.6007/IJARBSS/v10-i11/8168

DOI:10.6007/IJARBSS/v10-i11/8168

Received: 27 September 2020, Revised: 25 October 2020, Accepted: 15 November 2020

Published Online: 28 November 2020

In-Text Citation: (Alias et al., 2020)

To Cite this Article: Alias, J., Mat, N., Muslim, N., Abdullah, N. A., \& Senik, R. (2020). Innovation as a New Mode of Knowledge Transfer within MNC Subsidiary. International Journal of Academic Research in Business and Social Science, 10(11), 1049-1067.

Copyright: (c) 2020 The Author(s)

Published by Human Resource Management Academic Research Society (www.hrmars.com)

This article is published under the Creative Commons Attribution (CC BY 4.0) license. Anyone may reproduce, distribute, translate and create derivative works of this article (for both commercial and non-commercial purposes), subject to full attribution to the original publication and authors. The full terms of this license may be seen at: http://creativecommons.org/licences/by/4.0/legalcode

Vol. 10, No. 11, 2020, Pg. 1049 - 1067

Full Terms \& Conditions of access and use can be found at http://hrmars.com/index.php/pages/detail/publication-ethics 


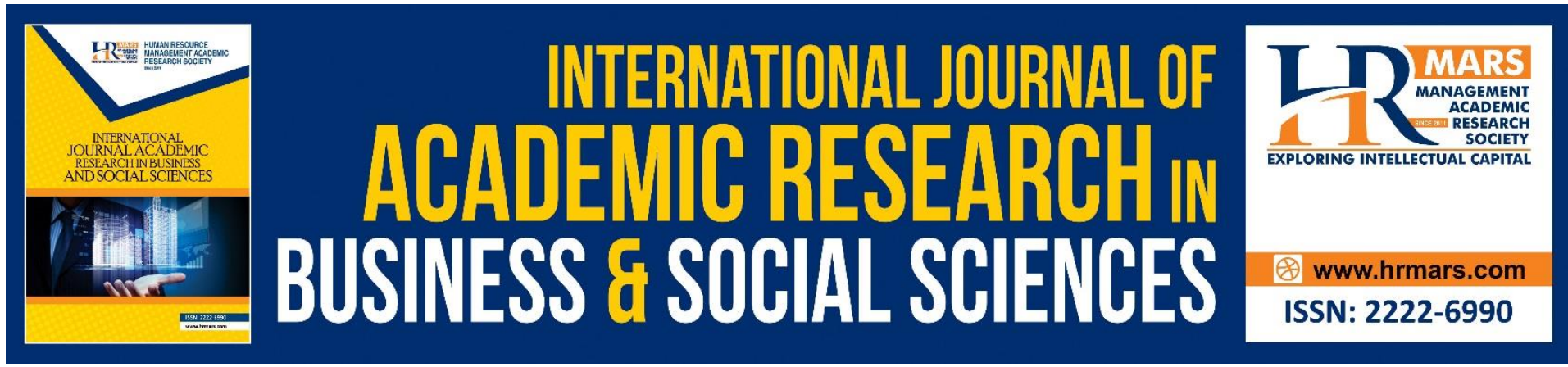

\title{
Innovation as a New Mode of Knowledge Transfer within MNC Subsidiary
}

\author{
Jamsari Alias ${ }^{1}$, Norazila Mat ${ }^{2}$, Nazri Muslim³ ${ }^{3}$, Nur Atiqah \\ Abdullah $^{2}$, \& Rosmila Senik ${ }^{4}$ \\ ${ }^{1 \& 3}$ Pusat Citra Universiti, Universiti Kebangsaan Malaysia, ${ }^{2}$ Faculty of Economics and \\ Management, Universiti Kebangsaan Malaysia, ${ }^{4}$ School of Business and Economics, \\ Universiti Putra Malaysia. \\ Email: jamsari@ukm.edu.my,norazila@ukm.edu.my
}

\begin{abstract}
With the growth of the multinational corporation (MNC) has come the need to understand how parent companies transfer knowledge to, and manage the operations of, their subsidiaries. Japanese companies in particular have been pioneering in this regard, with techniques such as the Toyota Production System (TPS) for transferring the ethos of Japanese manufacturing and maintaining quality and control in overseas subsidiaries. A great deal has been written about the process of transferring Japanese manufacturing techniques, but much less is understood about how the subsidiaries themselves, which are required to make use of such techniques, actually acquire and incorporate them into their operations. This paper examines how, from the perspective of the subsidiary, knowledge of manufacturing techniques, is transferred from the parent company. An in-depth qualitative research was, therefore, conducted in the subsidiary of a Japanese multinational, involving three main manufacturing initiatives (or philosophies), namely 'TPS', 'TPM' and 'TS'. The case data were derived from 52 in-depth interviews with project members, moderate-participant observations, and documentations. This study contributes to our understanding of knowledge transfer in relation to the approaches of adaptation and replication of knowledge within the subsidiary, how the whole process is developed, and also how a new mode of transfer, coined as 'innovation' takes place.
\end{abstract}

Keywords: Knowledge Transfer, Subsidiary in MNC, In-depth Practice-based View, Malaysia.

\section{Introduction}

Over the past forty years, a rapid development of multinational corporations (MNCs) has been seen. Scholars have been observing the aspects of economic investment as well as their existence and development, towards recently the aspect of knowledge, particularly on how MNCs manage its knowledge (Gupta and Govindarajan, 2000).

With this swift growth of MNCs, it has come the need to understand how parent companies transfer knowledge to, and manage the operations of, their subsidiaries (Alias et al, 2008a). This is of particular interest to manufacturing companies transferring their operations 
overseas. Japanese companies in particular have been pioneering the development of techniques such as Kaizen, and elements of the Toyota Production System (TPS) such as Kanban, which can be useful tools for transferring the ethos of Japanese manufacturing and maintaining quality and control in overseas subsidiaries (Alias et al., 2008b)

Knowledge transfer is defined as "the process through which one unit (e.g., group, department, or division) is affected by the experience of another" (Argote and Ingram, 2000: pg 151). Argote and Ingram (2000) further point out that the transfer of organisational knowledge (i.e., routine or best practices) can be observed through changes in the knowledge or performance of the recipient units. This process of knowledge transfer is becoming increasingly important in organisations especially in the multinational corporations (MNCs). The reason being effective management of these distributed organisations requires knowledge possessed by the organisations to be transferred from one individual, team, department, or geographical division to another (Alias, 2013).

MNCs generally operate in several countries but are managed from one home country. A home office company or head-quarters (HQ) of the MNC is normally referred to as the 'parent' while the companies operating in other countries are called 'subsidiaries'. The subsidiaries usually contribute greatly to the MNCs' revenue, being involved in substantial direct investment in foreign countries, with engagement in active management and integration of operations located in other different countries (Birkinshaw \& Hood, 1998).

Scholars have been observing the aspects of economic investment related to operations of MNCs as well as its existence and development for the past thirty years, but it is only relatively recently that the aspect of knowledge, particularly how MNCs manage their knowledge, has emerged (Gupta and Govindarajan, 1991; 2000). In the global economy, knowledge is a power that has become an important source of a competitive advantage to an organization, and thus it needs to be managed effectively (Malhotra, 2003). However, transferring knowledge is complex because of two main reasons. First, knowledge resides in organisational members, tools, tasks, and their sub-networks (Argote and Ingram, 2000). Secondly, much knowledge in organisations is tacit and hard to articulate (Nonaka and Takeuchi, 1995). With the fast growth pace of MNCs, there is a high need to understand how parent companies transfer their knowledge to, and manage the operations of, their subsidiaries (Alias et al, 2008b). This is of particular interest to manufacturing companies, specifically Japanese MNCs, which set many of their manufacturing operations in overseas locations. Japanese companies in particular have been pioneering in the development of techniques such as Kaizen, and elements of the Toyota Production System (TPS) such as Kanban, which can be useful tools for transferring the ethos of Japanese manufacturing and maintaining quality and control to overseas subsidiaries (Alias et al, 2008b).

The Japanese MNC provides a good contextual setting for a study of knowledge transfer. In the extant literature, scholars have developed widespread interests in the importance of knowledge management in firms, particularly, in MNCs (e.g., Ghoshal and Bartlett, 1988; Zander and Kogut, 1995; Szulanski, 1996; Gupta and Govindarajan, 2000; Eisenhardt and Santos, 2002; Birkinshaw et al, 2004) in which many projects involves various types of knowledge. This situation provides avenues for further investigations into this topic, 
especially involving subsidiaries located in other countries such as Malaysia (Alias et al, 2008a).

In general, most of the studies have focused on a macro perspective of knowledge transfer between parent companies and their subsidiaries regionally and globally (e.g., Nobel and Birkinshaw, 1998; Gupta and Govindarajan, 2000; Foss and Pedersen, 2002). Much have been written about the process of transferring Japanese manufacturing techniques, yet evidence is still lacking on the knowledge transfer process at the micro level, that is how the subsidiaries themselves make use of such techniques, acquire, and incorporate them into their operations. It is important to investigate the issue of knowledge transfer in a micro setting to enable a deeper understanding of the processes that occur inside of a subsidiary of a MNC, including the roles assumed by individuals in the process of knowledge transfer (Alias, 2013)

This research therefore, takes the perspective within the subsidiary to examine how knowledge of manufacturing techniques is transferred from a parent company to its subsidiaries by focussing on the projects within the subsidiary. According to Bresnen et al (2003) and Koskinen et al (2003), projects normally involve cross-sectional flows throughout the hierarchy of an organisation and its subsidiaries, involving personnel from different levels in the organisation. Projects are seen as the situations where most knowledge is created, shared and transferred. Thus, the process of knowledge transfer can be clearly observed and understood, and validity of the research is ensured (Alias et al, 2008b).

Specifically, this study examines the micro perspective of knowledge transfer by investigating a Japanese MNC's subsidiary in Malaysia with the aim of understanding how local managers and operations incorporate the transferred knowledge into their working practices. Substantially, the investigation of knowledge transfer from this position can explain what and how, the knowledge are transferred and implemented (Alias, 2013).

In terms of transferring knowledge between MNCs and their subsidiaries, two main approaches are normally used to fit in with the local condition, these being replication and adaptation (Szulanski et al, 2002; Williams, 2003). The term replication refers to a situation when knowledge is copied or reproduced from the original source. Adaptation of knowledge on the other hand, occurs when one (the recipient) makes adjustments to the knowledge. However, according to March (1991) and Szulanski (1996, 2000), the replication of knowledge is quite difficult to realise. Adaptation requires that the transferred practices fit with the local environment; however, focussing solely on fitting the practices may create a potential dilemma. As a result, even with experience, neither the MNC nor the subsidiary may fully understand the practice nor be able to completely codify the practice or the knowledge, making it becomes sticky, or difficult, to transfer (Szulanski, 1996; von Hippel, 1994).

\section{Knowledge Transfer wthin MNC Subsidiary}

The micro-setting of an MNC subsidiary will provide the opportunity to gain a deeper understanding in this respect, and this is in line with the suggestions about the need to take a practice-based view to understanding how local managers and operatives incorporate the knowledge into their working practices (Alias et al, 2008a). The Japanese MNC is indeed a good contextual setting for a study of knowledge flow, since over the last years, there has been a widespread interest among scholars in the importance of knowledge management in firms, particularly, in multinational corporations (e.g. Ghoshal and Bartlett, 1988; Zander and 
Kogut, 1995; Szulanski, 1996; Gupta and Govindarajan, 2000; Eisenhardt and Santos, 2002; Birkinshaw et al, 2004) in which the various types of knowledge flow have been investigated. In terms of transferring knowledge, two main approaches are used to fit in with the local condition, these being replication and adaptation. The significance of adaptation is that while it is sensible that the subsidiary, and hence the transferred practices that it uses, must achieve fit with the local environment, focussing solely on fit creates a potential dilemma (Alias et al, $2008 \mathrm{~b}$ ). As a result, even with experience, neither the multi-national firm (MNC) nor the subsidiary may fully understand the practice nor be able to completely codify it, making it become sticky, or difficult, to transfer (Szulanski, 1996; von Hippel, 1994).

Thus, one important established dimension to differentiate among knowledge transfers is the extent of exact copying of knowledge in other parts of the organisation, which is generally categorised as replication or adaptation (Szulanski, 2006). Replication refers to those knowledge transfers where a particular practice is copied in as detailed a way as possible (Alias et al, 2008b). On the other hand, adaptation allows the receiving unit to adapt the knowledge and make changes according to the idiosyncrasies of its context (Szulanski et al, 2002; Williams, 2002).

Researchers suggest that firms need to focus on replication in order to best leverage knowledge (Szulanski et al, 2002) although it has been found difficult (Szulanski, 1996; 2001). Empirical work by Williams found that investments in both replication and adaptation have a positive impact on knowledge transfer (Williams, 2002). Knowledge is also known to face the process of codification and needs to be de-codified for the transfer among experts to be achievable (Hall, 2006).

The previous studies on replication have found that the success of knowledge transfer depends on the accuracy of the replication (Szulanski and Cappetta 2000, Szulanski et al, 2000), and on its appropriate adaptation for the new organisational settings (Argote and Ingram, 2000), while in other work, scholars have treated adaptation as the absence or degradation of replication (Winter and Szulanski, 2001).

Different studies have revealed that organisations with a similar template of knowledge in actions are benefiting from much greater transfer than those that need to translate and adapt them (Nelson and Winter, 1982; Winter and Szulanski, 1998; Szulanski and Jensen, 2001; and Rivkin, 2001), and that transfer will inevitably require increasing adaptation as an organisation becomes more open and interdependent with its environment (Epple et al 1996; Winter and Szulanski, 1998).

In terms of seeking an in-depth understanding of the phenomenon of knowledge transfer, the Japanese MNCs would provide a good platform for a study as they are well known for their universal approach in transferring knowledge, particularly in the automotive industry (Kenney and Florida, 1995).

Therefore, when considering the issue of knowledge transfer, particularly when trying to gain an in-depth appreciation of the processes involved, the study environment should be selected not only to provide a good empirical ground for research, but also to be able to provide examples of different knowledge flows running concurrently. This is confirmed by Minbaeva 
(2007), who outlines the importance of paying attention to the individuals in the transfer process, in order to better understand it, as they are the heart of knowledge transfer projects. This is a condition that would fit in empirically to fill in the gap.

According to Kluge et al (2001), effective top-down and bottom-up communication is very important in making existing knowledge profitable to the organisation. However, effective communication across the hierarchy is tricky and this makes knowledge very difficult to transfer. If an organisation supports communication networks that operate freely, where knowledge provider and knowledge seekers can assess information and knowledge through shorter and effective paths, it will certainly enhance knowledge transfer within it (Alias et al, 2008a). Moreover, the application of the different levels of hierarchy and flow of order in an organisation has been found since the early phases of MNC initiatives such as in the zero defect programme and quality circles activities (Bennett, 1986).

More importantly if the contextual settings of the organisation are meant to facilitate projects involving knowledge flow from different directions that could suitably fit with the different flow and prescribed by the projects themselves. This involves the problem of knowledge explicated in databases or handbooks, routines and procedures vs. face-to-face contacts and meetings between organisational members, in which any other form of different communication flow in a related area is under exploration (Alias et al, 2008b).

Collectively, these views expressed in different studies, are refining and shaping the focus of research in this field, and opening up new insights, not only with regard to how the different knowledge flow processes have different impacts, but also on how the processes are involved and take place (Alias et al, 2008b).

As Davenport and Prusak (1998) argue, the transfer of knowledge of value to the organisations involves both the transmission of information to a recipient and the absorption and transformation by that person or group. This transfer of knowledge should lead to changes in behaviour, changes in practices and policies and the development of new ideas, processes, practices and policies (Bender and Fish, 2000).

Therefore, the main objectives of this paper are:

- to understand the processes of MNC parent companies transfer knowledge of manufacturing operations to their subsidiaries.

- to explore how the subsidiaries replicate and adapt knowledge from their parents companies

- to understand the circumstances in which replication or adaptation occurs

\section{Gambatte Corporation: The Research Context}

The Gambatte* Corporation (* anonymously mentioned as Gambatte) is a leading supplier of advanced automotive technology, systems and components for all the world's major automakers (Alias et al, 2008b). It operates in 32 countries and regions with more than 112,000 employees who are active in all aspects of the automotive business. Sales, product development and design and manufacturing, and working in co-operation with regional car manufacturers and suppliers to provide the most suitable solutions to regional requirements, 
gave the Corporation global consolidated sales totalling US $\$ 30.6$ billion for the fiscal year ended March 31, 2007 (Gambatte, 2007).

The management principles of Gambatte are focused on customer satisfaction through the provision of quality products and services, global growth through anticipation of changes, environmental preservation and harmony with society, corporate vitality, respect for individuality, and each Gambatte associate (employee) must possess the Gambatte spirit of creativity in thought and steady in action, be co-operative and pioneering as well as trustworthy (Gambatte, 2007 \& Alias et al, 2008b).

Gambatte (Malaysia), which is the research site selected for this paper is a subsidiary wholly owned by Gambatte Corp, and was established in 1980 since when it has become the largest automotive components manufacturer in Malaysia today, and a major automotive components supplier to the national car projects as well as to Japanese cars built in Malaysia (Alias et al, 2008b). Instantly associated with quality, Gambatte continuously selects and implements improvement efforts that have the greatest impact on the key business plans and goals. This is done by continually focusing on achieving high quality and productivity, by optimizing product design and reducing waste, and by variation in manufacturing process (Alias et al, 2008b).

Gambatte (M) has always taken innovative actions ahead of time. It is among the first in the Gambatte Group of Companies that has been awarded the prestigious ISO/TS 16949 by the SIRIM and "International Automotive Task Force (IATF)", a body that represents car-makers and suppliers worldwide. The company is also certified in the ISO 14001 Environmental Management System which recognises commitment and effort in maintaining the environment (Alias et al, 2008).

There are numerous projects running in this plant site, but three main ones are purposely selected to suit the three main manufacturing initiatives (philosophies) that would provide into a clearer understanding on how they are transferred.

\section{Case 1 - Gambatte TPS (Toyota Production System)}

The history of Gambatte TPS goes back to 1973 at GJP (Gambatte Japan - the HQ of Gambatte Group). This was originated from Kaizen Activity instructed by the Toyota Motor Corporation, which designed this TPS system, and that is how it got its name - Toyota Production System (TPS), which has becoming a worldwide recognisable established manufacturing standard, especially in the automotive sector, and particularly relating to the lean production initiatives (Alias et al, 2008b).

Since 1996, the line improvement (kaizen) efforts were held individually. Individually in this context should not be understood as an individual person per se, but rather as an initiative that was conducted individually in separate departments where the members were attached, thus bringing only minimal impact to the company in total (Alias et al, 2008b).

Come 2002, a company-wide TPS team was established (initially known as the Kaizen Project Team). It combined all the members to start the first improvement in the Condenser Line in the Thermal System Plant. This involved close transfer supervision from the Japanese HQ manager who came to GMY to conduct the first training in respect of Kanban Simulation. 
In 2003, the Kaizen Project Team was restructured to become the TPS Project Team with eight members who were directly seen by the MD. In 2004, the TPS Team was expanded to two sections, namely the Improvement Team and Small Fabrication. The former section focuses on line improvement while the latter helps with the machinery or equipment-related items. Finally, last year in 2005, this TPS project team was upgraded to be a department by itself, and this reorganisation made the TPS Department a company-wide activity (Alias et al, 2008b).

This TPS Department Project provided the researcher with the main empirical location of the research, where the researcher interviewed key personnel and observed their relationships formally in their meetings as well as their informal interactions.

\section{Case 2 - Gambatte TPM (Total Productive Maintenance)}

TPM stands for Total Productive Maintenance. The history of the Gambatte TPM Project goes back 40 years to GJP (Gambatte Japan - the HQ of Gambatte Group). However, in Gambatte Malaysia (GMY), TPM is quite different from that reported in textbooks as it is actually more towards a management type of activity or job, in the matter of how to co-ordinate it to benchmark against the international activity, because TPM is considered as an international kind of activity. TPM involves machines, how machines are kept, or maintained in general, and has an emphasis on how to improve machine maintenance in general, which involves looking into who handles the machines, what systems maintain the machines, and how to enhance machine knowledge, which of course requires education and training (Alias et al, 2008b).

TPM in GMY involves the implementation and co-ordination of all these activities, "as a system, and TPM in Gambatte is a unique activity by itself, it's not only like the normal TPM per se in the international market where there are pillars, elements and so on, but the TPM that was brought to us from GJP to GMY is more on Gambatte way of TPM. It is very unique activity because in TPM the Gambatte way, we are looking at a very specific area, on maintenance management", said Mr M, the GM (TPM co-ordinator) (Alias, 2013).

\section{Case 3 - Gambatte TS Project}

TS16949 is the new international system tailored for the automobile world. As in TPS and TPM, the researcher managed to interview intensively with the co-ordinator of the project who is also the GMY Quality Director, Mr N. The TS team consists of a group of middle management from each department in GMY. Hierarchically they are similar, in the middle zone (Alias et al, 2008b).

TS16949 is the new system, before which there were ISO9000 and 9001, which are well known systems that have been implemented since 1994. Unlike the others however, TS applies additional requirements over and above ISO requirements that the Gambatte team members are quite familiar with, and in order to fully understand this new system, GMY has had to engage an external consultant, to teach the team what is expected by the system and how to implement it (Alias et al, 2008b). 


\section{Methodology, Aims and Questions}

It is clear from the above review that while the issue of knowledge transfer in MNCs has received considerable attention in the literature, there is still a lack of knowledge about how subsidiaries incorporate knowledge about manufacturing techniques from their parent companies.

The aim of this paper is, therefore, to understand the processes by which parent companies transfer knowledge of manufacturing operations to their subsidiaries. Additionally, a particularly relevant theme is how subsidiaries both replicate and adapt knowledge from parents and the circumstances in which replication or adaptation occurs.

The main research questions are:

- How do parent companies transfer knowledge of manufacturing operations to their subsidiaries and how is the knowledge being transferred within the subsidiary?

The methodological approach involves a qualitative case study, using three cases from three different projects in a subsidiary of an MNC (GMY) that involves three main manufacturing initiatives (philosophies).

This case study is an empirical inquiry that investigates a contemporary phenomenon within a real-life context where the boundaries between phenomenon and context are not clearly evident, and in which multiple sources of evidence are used. This is a preferred strategy when "the investigation has little control over events and when the focus is on a contemporary phenomenon within some real-life context and its generalisability is determined by strength of the description of the context" (Yin, 1984, p23).

The case study approach is useful when a phenomenon is broad and complex, when a holistic, in-depth, investigation is needed, and when a phenomenon cannot be studied outside the context in which it occurs (Yin, 1994) and case study will typically combine several qualitative data collection methods such as interviews, documentation, and observations, but can also include quantitative data such as questionnaires and time-series (Dube and Pare, 2003).

The study takes an inductive approach using qualitative methods and draws upon data collected from the three cases; TPS, TPM and TS from GMY. The data were derived from 52 individual interviews with project members, moderate-participant observations, and associated documentations.

The whole data comprises 52 interviews of 60-90 minutes each, nine meetings including formal and ad-hoc meetings, one open seminar, two staff training sessions, three plant tours, five meals and informal functions, and documentation of project materials. The process of data generation was a long-term one that included a series of e-mails and telephone conversations. The interview and meeting data produced more than 900 pages of transcription. Related photographs, documentation and images were also collected throughout the data collection process.

The data were analysed using thematic analysis based on Boyatzis (1998). All interviews were tape recorded and transcribed for analysis which involved deductive coding (based on previous literatures) as outlined in the template organising style by Crabtree and Miller 
(1999), and also the inductive coding (themes emerging from the interviews) approach of Boyatzis (1998). The data were analysed using identifiable broad themes and patterns in the textual data derived from interview transcriptions (Alias, 2013).

Data collection and analysis are interwoven in qualitative research. Once coding was completed, the codes that had common elements were merged to form categories and the coded sections of data were placed in categories in the data collection methods used. Some codes were placed in more than one category. The categorised data were then printed and stored manually in files with the name of each category. The categories derived from each data collection method were then clustered around each research question (Alias et al, 2008c).

Then, the related patterns were combined into sub-themes and the themes and sub-themes that emerged were gathered together. Further validation was achieved by checking with the literature, and on some occasions by asking the interviewees for feedback, thus making the theme analysis much more concrete. The qualitative data were also analysed using a constant-comparative method where the saturated points were achieved to be validated by the new findings. This process was instrumental in getting the answers to the research questions (Alias et al, 2008c).

Where events or conversations had been recorded in more than one of the methods used (for example, in observation and interviews), both transcripts were reviewed together after initial coding. Then journal entries were reviewed to check if there was any evidence of extraneous circumstances influencing the researcher's interpretation of events, or impinging on the event being recorded, and to review any other interpretations that were perceived at the time.

\section{Findings and Discussions on Approaches in Knowledge Transfer}

The findings are intended to draw attention to the need for understanding of how knowledge transfer occurs within the subsidiary. The data analysis indicates that knowledge are transferred through three main approaches, which are replication, adaptation, and innovation.

Extent literature on knowledge transfer literature reveals two main approaches to knowledge transfer, namely, replication and adaptation. For the purposes of recapitulation, it can be said that when knowledge is copied or reproduced, the term replication is used to indicate that it is a direct imitation of the original source. Adaptation, on the other hand, is used to refer to the situation when some adjustments are made to the knowledge (Szulanski, 1996, von Hippel, 1994).

In this study, replication occurs when there is a need for repetition, with the transferred knowledge strictly mirroring the original knowledge. Replication is also apparent when there is more documentation and standardisation required by the parent company. In the case of adaptation, however, knowledge is manipulated somewhat to ensure the need for understanding is met, and in this case explanations are required. Additionally, there is often a need for additional jobs and tasks, and in such instances adaptation occurs so that some adjustments can be done. 
Whilst Williams (2003: 2007) has made the generalised comment that replication requires a more discrete approach, and adaptation requires more understanding, additional contributions have been made to the literature by this study providing details of the dimensions, criteria and categories of what and how these approaches actually work in real life situations.

And the novelty of the emerging themes from the knowledge transfer approaches is when a third approach is found from this study, which is referred to as "innovation". From the data, it is found that innovation takes place when new interpretations are created on the knowledge transferred using totally new ways of carrying out the tasks. Another key theme of innovation is when new knowledge is required to solve existing problems.

According to the literature, knowledge transfer is mostly intended from the parent MNC to the subsidiary (Gupta \& Govindarajan, 2000). This study extends the literature on knowledge transfer, suggesting that many occurrences of knowledge transfer happened within the subsidiary itself and that the subsidiary make many decisions on the knowledge transfer approach to be utilized. The themes of criteria explicating when knowledge transfer approaches are selected through replication, adaptation or innovation are explained in the previous part together with the quotations that support them.

The findings of activities are portrayed into 16 episodes, where it can be observed that when the same manufacturing techniques of lean manufacturing or TPS system is implemented in the subsidiary, direct copying (replication) or making adjustment (adaptation) is based on the choice of the subsidiary itself. This goes the same for TS systems and TPM implementations.

From the findings of the activities of episodes, we can gather another interesting feature. The more systematic and structured the manufacturing techniques that are transferred from the parent, for instance on the TS project, the more replications are applied, while the more conceptual, robust, open and flexible the manufacturing techniques coming from the parent, for instance on TPS project, the more innovations are applied.

The table and pie charts below explain the findings. From the 16 episodes, TS related episodes are elaborated in Episodes number 1, 4, 6, 13 and 14. Therefore, extracting the summary tables of activities from these five episodes, we would get the following overall TS activities table and chart:

Table 1: Overall TS Activities Table

\begin{tabular}{|c|c|c|c|}
\hline TS & Replication & Adaptation & Innovation \\
\hline 34 Activities & 23 & 11 & 0 \\
\hline
\end{tabular}

Summary of TS Activities Represent Replication, Adaptation and Innovation 


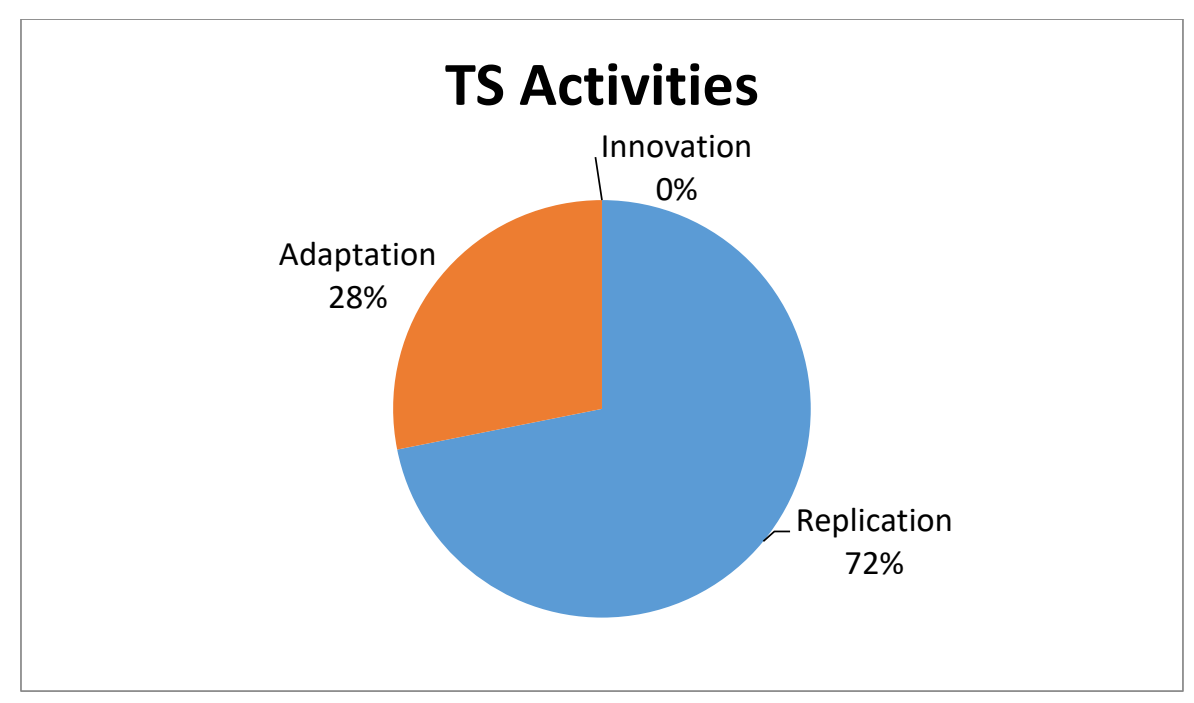

\section{Figure 1: TS activities chart}

TS is a project of manufacturing techniques nature focusing on complying the systems which are mostly related to systems involving TS16949 as well as QS9000 and ISO 9001:2000. Thus, the nature of the knowledge transferred is in terms of more systematically compliance and strictly endorsed and applied what have been described from the parent. These activities are exhibited in a series of episodes in chapter Five related to TS in episodes number 1, 4, 6, 13 and 14. Based on the five episodes from the thirty-two (32) TS activities overall, knowledge is transferred through 23 activities of replication ( 72 percent), while adaptation occurred in 9 activities ( 28 percent), with no activities being transferred by innovation.

Next, from the 16 episodes, TPM related episodes are elaborated in Episodes number 5, 7, 8, 15 and 16 . Therefore, extracting the summary tables of activities from these five episodes, we would get the following overall TPM activities table and chart:

Table 2 : Overall TPM Activities Table

\begin{tabular}{|c|c|c|c|}
\hline TPM & Replication & Adaptation & Innovation \\
\hline 36 Activities & 8 & 27 & 1 \\
\hline
\end{tabular}

Summary of TPM Activities Represent Replication, Adaptation and Innovation 


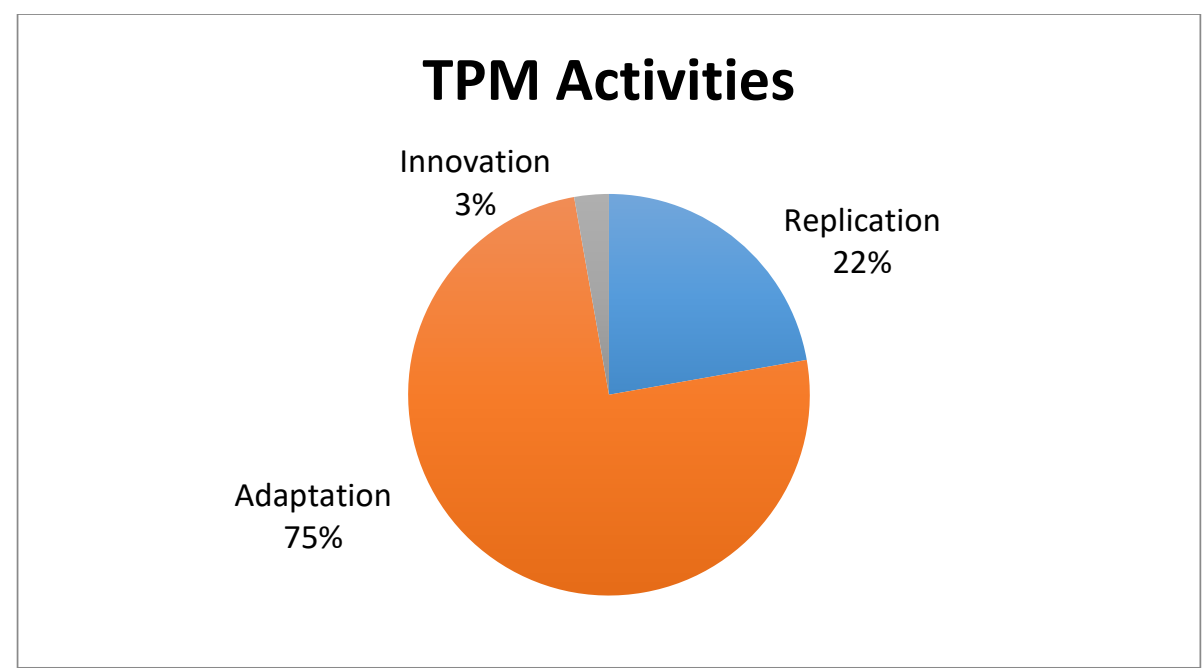

Figure 2: TPM activities chart

For the TPM project, which is about implementing manufacturing techniques related to comprehensive maintenance, the nature of the knowledge transferred is more of adaptation from the parent. These activities are elaborated in episodes numbers 5, 7, 8, 15 and 16 . Therefore, it is clearly shown here that from the overall 36 TPM activities; knowledge transfer took place through adaptation, 27 activities (or 75 percent), while replication 8 (or 22 percent), and innovation with only 1 activity ( 3 percent).

While from the 16 episodes, TPS related episodes are elaborated in Episodes number 2, 3, 9, 10, 11 and 12. Therefore, extracting the summary tables of activities from these six episodes, we would get the following overall TPS activities table and chart:

Table 3: Overall TPS Activities Table

Summary of TPS Activities Represent Replication, Adaptation and Innovation

\begin{tabular}{|c|c|c|c|}
\hline TPS & Replication & Adaptation & Innovation \\
\hline 40 Activities & 3 & 13 & 24 \\
\hline
\end{tabular}

\section{TPS Activities}

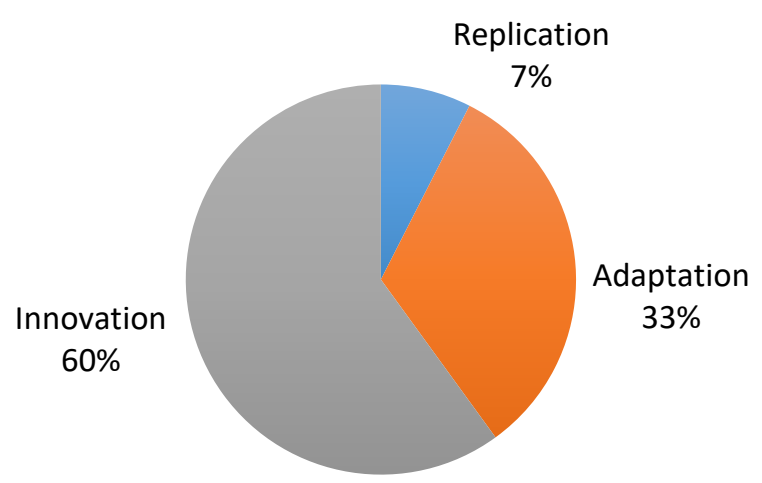

Figure 3: TPS activities chart 
Finally for TPS project, which is about applying new manufacturing techniques of TPS system or lean manufacturing that is related to dynamic manufacturing processes, the approach of the knowledge transferred from the parent is classified as innovation. These findings are illustrated in episodes related to TPS in six episodes (numbers 2, 3, 9, 10, 11 and 12). More interestingly, some of the innovation originated here in Gambatte Malaysia are applied and used in other Gambatte's subsidiaries in the Asean region as well as received recognition by the parent in Japan. Therefore, it is clearly shown here that from the overall 40 TPS activities from the 6 episodes; knowledge transfer took place through innovation 24 times (60 percent), while adaptation was in 13 activities (33 percent) and replication 3 activities (7 percent).

The findings of this study may also help to explain that there are circumstances in replication and adaptation, within a project context of knowledge transfer, and even suggests 'innovation' as a new approach to knowledge transfer on its own. Previous research focused on knowledge transfer via replication and adaptation in general; however, this study delved further by considering their circumstances in an organisational project context (Alias, 2013).

In short, the summary of the new findings can be tabled as below:

Table 4: Summary of the Findings

\begin{tabular}{|l|l|l|l|}
\hline $\begin{array}{l}\text { Research } \\
\text { Objectives }\end{array}$ & Data Analysis & $\begin{array}{l}\text { Research } \\
\text { Contributions }\end{array}$ & $\begin{array}{l}\text { Contributions to } \\
\text { Theories }\end{array}$ \\
\hline $\begin{array}{l}\text { 1. To explore how } \\
\text { knowledge is } \\
\text { transferred within } \\
\text { an MNC subsidiary } \\
\text { and how it is } \\
\text { developed into the } \\
\text { context of } \\
\text { organisational } \\
\text { projects }\end{array}$ & $\begin{array}{l}\text { Applies thematic } \\
\text { analysis approach by } \\
\text { investigating the } \\
\text { development of } \\
\text { themes based on the } \\
\text { episodes, interviews, } \\
\text { observations and } \\
\text { documentations. }\end{array}$ & $\begin{array}{l}\text { Produces a clear } \\
\text { understanding of } \\
\text { how knowledge } \\
\text { transfer actually } \\
\text { happens in real } \\
\text { settings. }\end{array}$ & $\begin{array}{l}\text { Enriching the } \\
\text { Knowledge } \\
\text { Transfer and } \\
\text { Knowledge } \\
\text { Management } \\
\text { Theory }\end{array}$ \\
\hline $\begin{array}{l}\text { Discovers a new } \\
\text { approach of } \\
\text { "innovation". }\end{array}$ & \\
\hline
\end{tabular}

\section{Conclusion}

This study has enriched the discussion on current knowledge transfer literature. By applying an inductive qualitative case study with a thematic analysis, this study explores knowledge transfer within a subsidiary of an MNC during project implementation.

This study contributes to the knowledge transfer body of knowledge by empirically examining the dimensions, and characteristics of knowledge transfer. Findings from this study provide a basis for understanding the process of knowledge transfer in a project context, particularly within a subsidiary of the MNCs. With this knowledge, implications for practice are identified and recommendations for future research are suggested.

The findings of this study offered three important contributions to the understanding of knowledge transfer and its significance in a subsidiary of MNCs by:

1. Drawing on the rich data of three projects in a MNC's subsidiary's experiences, the study generates an understanding of how knowledge is transferred within the context 
of a subsidiary by providing details of the approaches to knowledge transfer within the subsidiary.

2. Incorporating the findings from this study with the insights from knowledge transfer of manufacturing techniques and practices from the literature help researchers and practitioners to clarify the process of replication and adaptation in MNC subsidiary knowledge transfer. The study generates a list of the significant categories and items of replication and adaptation for knowledge transfer in the project context; and

3. Dealing with the multi-faceted project context, this study adds significant content to researchers' and practitioners' understanding of knowledge transfer, particularly in replication and adaptation approaches as well as another emergent approach referred to as the "innovation" approach.

To conclude, this study proves that replication and adaptation occur differently with their own unique circumstances. It also suggests that the dimensions of replication and adaptation may occur in a certain way, but require time to evolve. Interestingly, on top of that, a new and novel approach of 'innovation' was also developed. All in all, these findings would enrich the knowledge transfer aspect in particular and knowledge management field in general.

\section{Acknowledgement}

This study is sponsored by research grants from Universiti Kebangsaan Malaysia; under Research Code GGP-2018-006 and Research Code EP-2019-034.

\section{References}

Alavi, M., and Leidner, D. (2001). Knowledge management and knowledge management systems: Conceptual foundations and research issues. MIS Quarterly 25(1), pp 107136.

Alias, J. (2013). Transferring Knowledge of Manufacturing Techniques within a Subsidiary of a Multinational Corporation. PhD thesis, Aston Business School, Aston University, United Kingdom.

Alias, J., Bennett, D. J., and Hall, M. (2008a). Transferring Knowledge of Manufacturing Techniques in Multinational Corporations: Preliminary Findings, in Jolly D (Ed) Proceedings of $3^{\text {rd }}$ European Conference on Management of Technology, CERAM/IAMOT, Nice, France, ISBN 0-9815817-1-4 (CD).

Alias, J., Bennett, D. J., and Hall, M. (2008b). Transferring Knowledge of Manufacturing Techniques in Multi-National Corporations: A Review of the Literature, in Harorimana $\mathrm{D}$ and Watkins D (Eds) Proceedings of $9^{\text {th }}$ European Conference on Knowledge Management, Academic Publishing International, Reading, UK, ISBN: 978-1-90663811-5 (pp 11-18).

Alias, J. (2008c). Knowledge Transfer in Different Knowledge Flows of Projects: Towards a Contingency Approach, in International Technology, Education and Development Conferences, INTED2008 Proceedings; Valencia, Spain, ISBN: 978-84-612-0190-7

Alvesson, M. and Karreman, D. (2001). Odd couple: Making sense of the curious concept of knowledge management. Journal of Management Studies 38(7), pp 995-1018.

Argote, L. and Ingram, P. (2000). Knowledge transfer: A basis for competitive advantage in firms, Organisational Behaviour and Human Decision Processes 82(1), pp 150-169.

Argote. L. (1999). Organisational Learning: Creating, Retaining, and Transferring Knowledge. Boston: Kluwer Academic. 
Bender, S., and Fish, A. (2000). The transfer of knowledge and the retention of expertise: the continuing need for global assignments, Journal of Knowledge Management 4(2), pp 125-137.

Bennett, D. (1986). Production Systems Design. London: Butterworths Ltd.

Birkinshaw, J. (1996). How multinational subsidiary mandates are gained and lost. Journal of International Business Studies 27(3), pp 467-495.

Blackler, F. (1993). Knowledge and the theory of organisations: Organisations as activity systems and the reframing of management, Journal of Management Studies 30(6), pp 863-884.

Blackler, F. (1995). Knowledge, knowledge work and organisations: An overview and interpretation. Organisation Studies 16(6), pp 1021-1046.

Boyatzis, R. E. (1998). Transforming Qualitative Information: Thematic Analysis and Code Development. London: Sage Publications.

Broner, N., Franczak, M., Dye, C., and McAllister, W. (2001). Knowledge transfer, policymaking and community empowerment: A consensus model approach for providing public mental health and substance abuse services, Psychiatric Quarterly 72(1), pp 79-102.

Chini, T. (2005). Effective Knowledge Transfer in Multinational Corporations. Basingstoke: Palgrave Macmillan.

Crabtree, B., and Miller, W. (1999) A template approach to text analysis: Developing and using codebooks, in Crabtree, B. and Miller, W. (Eds.), Doing Qualitative Research, Newbury Park, CA: Sage, pp 163-177.

Darwish, S., Ahmed, U., \& Pahi, M. H. (2020). Innovative Work Behavior During COVID-19 for Medical Representative in the Pharmaceutical Industry: Test of a Moderation Model in Bahrain. International Journal of Pharmaceutical Research. 12(4), 19271934. doi.org/10.31838/ijpr/2020.12.04.277.

Davenport, T. H., and Prusak, L. (1998). Working Knowledge: How Organisations Manage What They Know. Boston: Harvard Business School Press.

Davenport, T. H., De Long, K. M., and Beers, K. C. (1998). Successful knowledge management projects, Sloan Management Review 39(2), pp 43-57.

Decter, M., Bennett, D. and Leseure, M. (2007). University to business technology transfer UK and USA comparison, Technovation 27(3), pp 145-155.

Delbridge, R., and Barton, H. (2002). Organizing for continuous improvement: structures and roles in automotive components plants. International Journal of Operations and Production Management 22(6), pp 680-692.

Demsetz, H. (1988). The theory of the firm revisited, Journal of Law, Economics and Organisation, 4(1), pp 141-161.

Doz, Y., Santos, J., and Williamson, P. (2001). From Global to Metanational: How Companies Win in the Knowledge Economy, Boston, Harvard Business School Press.

Edwards, J. S., Shaw, D., and Collier, P. M. (2005). Knowledge management systems: Finding a way with technology, Journal of Knowledge Management 9(1), pp 113-125.

Eisenhardt, K. M. (1989). Building theories from case study research, Academy of Management Review 14(1), pp 532-550.

Eisenhardt, K. M., and Santos, F. M. (2002). Knowledge based view: A new theory of strategy in Pettigrew, A. M., Thomas, A. and Whittington, R. (Eds), Handbook of Strategy and Management, London, Sage, pp 139-164.

Galbraith, C. S. (1990). Transferring core manufacturing technologies in high-technology firms, California Management Review 32(4) pp 56-70. 
Ghoshal, S., and Bartlett, C. A. (1988). Creation, adoption and diffusion of innovations by subsidiaries of multinational corporations, Journal of International Business Studies 19(3), pp 365-388.

Glaser, E. M., Abelson, H. H., and Garrison, K. N.(1983). Putting Knowledge to Use: facilitating the diffusion of knowledge and the implementation of planned change. San Francisco, CA: Jossey-Bass.

Gnyawali, D. R., Stewart, A. C., and Grant, J. H. (1997). Creating and utilization of organisational knowledge: An empirical study of the roles of organisational learning on strategic decision making. Academy of Management Best Paper Proceedings, pp 16-20.

Gore, C., and Gore, E. (1999). Knowledge management: The way forward, Total Quality Management 10(4), pp 564-560.

Grant, R. M. (1996). Toward a knowledge-based theory of the firm, Strategic Management Journal 17, pp 109-22.

Grant, R. M. (1996b). Prospering in dynamically-competitive environments: Organisational capability as knowledge integration, Organisation Science 7(4) pp 375-387.

Gupta, A. K., and Govindarajan, V. (1991). Knowledge flows and the structure of control within multinational corporations, Academy of Management Review 16 (4), pp. 768-792.

Gupta, A. K., and Govindarajan, V. (2000). Knowledge flows within multinational corporations, Strategic Management Journal 21(4), pp 473-496.

Hall, M. (2006). Knowledge management and the limits of knowledge codification, Journal of Knowledge Management 10(3), pp 117-126.

Hamel G. (1991). Competition for competence and inter-partner learning with international strategic alliances, Strategic Management Journal 12(1), pp.83-103.

Hansen, M. (1999). The search transfer problem, Administrative Science Quarterly 44(1), pp 82-111.

Hassard, J. (1991). Multiple paradigms and organisational analysis: A case study, Organisation Studies 12(2), pp 275-299.

Inkpen, A. C., and Dinur, A. (1998). Knowledge management processes and international joint ventures, Organisation Science 9(4), pp 454-468.

Inkpen, A. (1998). Learning and knowledge acquisition through international strategic alliance, Academy of Management Executive 12(4), pp 69-80.

Inkpen, A. (2005). Learning through alliances: General motors and NUMMI, California Management Review 47(4), pp 114-136.

Jashapara, A. (2004) .Knowledge Management: An Integrated Approach. Prentice-Hall

Kenney, M., and Florida, R. (1995). The transfer of japanese management styles in two US transplant industries: autos and electronics, Journal of Management Studies 32(6), pp 789-802.

Kogut, B., and Zander, U. (1995). Knowledge, market failure and the multinational enterprise: A reply. Journal of International Business Studies 26(2), p417.

Kogut, B., and Zander, U. (1992). Knowledge of the firm, combinative capabilities, and the replication of technology, Organisation Science 3(3), pp 383-397

Koskinen, K. U. (2003). Evaluation of Tacit Knowledge Utilization in Work Units. Journal of Knowledge Management, 7(5), pp 67-81.

Kostova, T. (1999). Transnational transfer of strategic organisational practices: A contextual perspective, Academy of Management Review 24 (2), pp 308-324. 
Lane, P. J., and Lubatkin, M. (1998). Relative absorptive capacity and inter-organizational learning, Strategic Management Journal 19(5), pp 461-477.

Liebeskind, J. P. (1996). Knowledge, strategy, and the theory of the firm, Strategic Management Journal 17, pp 93-107.

Minbaeva, D. B., and Michailova, S. (2004). Knowledge transfer and expatriation in multinational corporations, Employee Relations 26(6), pp 663-679.

Minbaeva, D. B. (2005). HRM practices and MNC knowledge transfer, Personnel Review 34(1), pp 125-144.

Minbaeva, D. B. (2007). Knowledge transfer in multinational corporations, Management International Review 47(4), pp 567-593.

Monden, Y. (1983). Toyota Production System: Practical Approach to Production Management, Georgia: IEMP-IIE.

Nelson, R. R., and Winter, S. G. (1982). An Evolution Theory of Economic Change, Harvard University Press.

Nissen, M., Kamel, M., and Sengupta, K. (2000). Integrated analysis and design of knowledge systems and processes, Information Resources Management Journal 13(1), pp 181204.

Nissen, M. E. (2002). An extended model of knowledge-flow dynamics, Communications of the Association for Information Systems 8, pp 251-266

Nonaka, I. (1991). The knowledge creating company, Harvard Business Review, 69(6), pp 96104.

Nonaka, I. (1994). A dynamic theory of organisational knowledge creation. Organisation Science 5(1), pp 14-37.

Nonaka, I., and Takeuchi, H. (1995). The Knowledge-Creating Company. Oxford University Press.

Oliver, N., and Wilkinson, B. (1992). The Japanisation of British Industry, 2nd ed, Oxford, Blackwell.

Oliver, N., Delbridge, R. and Lowe, J. (1998). Japanisation on the Shopfloor, Employee Relations 20(3), pp 248-260.

Peterson, T., Sun, R., Merrill, E. (2001). From implicit skills to explicit knowledge: a bottom-up model of skill learning. Cognitive Science 25(2), pp 203-244.

Polanyi, M. (1962). Personal Knowledge. Chicago, University of Chicago Press.

Polanyi, M. (1967). The tacit dimension. New York, Doubleday

Polanyi, M. (1998). Personal Knowledge: Towards a Post-Critical Philosophy. London, Routledge

Rosenthal, F. (1970). Knowledge Triumphant: The Concept of Knowledge in Medieval Islam, Leiden, EJ Brill.

Schlegelmilch, B. B., and Chini, T. C. (2003). Knowledge transfer between marketing functions in multinational companies: a conceptual model, International Business Review, 12(2), pp 215-232..

Schniederjans, M. J. (1993). Topics in Just-In-Time Management, Boston, Allyn and Bacon.

Schonberger, R. J. (1982). Japanese Manufacturing Techniques: Nine Hidden Lessons in Simplicity, New York, The Free Press.

Schonberger, R. J. (1986). World Class Manufacturing: The Lessons of Simplicity Applied, New York, The Free Press.

Schonberger, R. J. (1995). TQM: What's in it for academics? Business Horizons 38(1), pp 6770. 
Simmonin, B. L. (1997). The importance of developing collaborative know-how: an empirical test of the learning organisation, Academy of Management Journal 40(5), pp 11501174.

Simonin, B. (2004), An empirical investigation of the process of knowledge transfer in international strategic alliances, Journal of International Business Studies 35, pp 407427.

Strauss, A., and Corbin, J. (1990). Basic of Qualitative Research: Grounded Theory Procedures and Techniques Newbury Park, CA, Sage Publication.

Strauss, A., and Corbin, J. (1998). Basic of Qualitative Research: Technique and procedures for developing Grounded Theory Thousand Oaks, CA, Sage Publication.

Szulanski, G. (2000). The process of knowledge transfer: A diachronic analysis of stickiness, Organisational Behaviour and Human Decision Processes 82(1), pp 9-27.

Szulanski, G. (1996). Exploring internal stickiness: Impediments to the transfer of best practice within the firm, Strategic Management Journal 17: 27-43.

Szulanski, G., Winter, S. G., Cappetta, R., Vanden, C. (2002). Opening the Black box of Knowledge Transfer: the role of replication accuracy, Wharton.

Szulanski, G., \& Sidney. (2002). Getting It Right the Second Time. Harvard Business Review 80(1), pp 62-71.

Teece, D. J., and Jorde, T. M. (1990). Innovation and Cooperation: Implications for Competition and Antitrust, The Journal of Economic Perspectives, 4(3), pp75-96.

Turnbull, P. (1988). The limits to Japanisation - just-in-time, labour relations and the UK automotive industry, New Technology, Work and Employment 3(1), pp.7-20.

Urakami, K. (2000). Notes on Japanese Multinational Companies, http://www2.odn.ne.jp/kurakami/japco

Von Krough, G., Ichijo, K., and Nonaka, I. (2000). Enabling Knowledge Creation: How to Unlock the Mystery of Tacit Knowledge and Release the Power of Innovation. New York, NY: Oxford University Press.

Williams, J. (2002). Practical issues in knowledge management, IT Professional 4(1), pp 35-39. Winter, S. G. (1987). Knowledge and Competence as Strategic Assets, Ballinger.

Yin, R. K. (1984). Case study research: design and methods, Sage Publications.

Yin, R. K. (1994). Case Study Research: Design and Methods (2nd ed). California: Sage Publication. 